\title{
The Equity Risk Premium: An Annotated Bibliography
}

\author{
Zhiyi Song, CFA \\ Greenwich Alternative Investments \\ Hong Kong
}

The equity risk premium is broadly defined as the difference between the expected total return on an equity index and the return on a riskless asset. The magnitude of the equity risk premium, arguably the most important variable in financial economics, affects the asset allocation decisions of individual and institutional investors, and the premium is a critical factor in estimating companies' costs of capital. This literature review explores research by academics and practitioners on this topic during the past three decades.

The equity risk premium (or, simply, equity premium) is broadly defined as the difference between the expected total return on an equity index and the return on a riskless asset. (Which index and which riskless asset need to be defined precisely before numerically estimating this premium.) The equity premium is considered the most important variable in financial economics. The magnitude of the equity premium strongly affects the asset allocation decisions of individual investors and institutional investors, including pensions, endowment funds, foundations, and insurance companies, and is a critical factor in estimating companies' costs of capital.

\section{History of Research on the Equity Risk Premium}

The topic of the equity risk premium (ERP) has attracted attention from academics and practitioners. There are three major themes in the intellectual history of the equity premium. The first theme builds on Gordon and Shapiro's suggestion that a dividend discount model (DDM) be used to estimate the required return on capital for a corporate project, and, by extension, the expected return on an equity (if the equity is fairly priced). 1 Specifically, the DDM says that expected total equity return equals the dividend yield plus the expected dividend growth rate; the equity premium is this sum minus the riskless rate. The DDM was widely used by practitioners to estimate the equity premium until Ibbotson and Sinquefield (1976) introduced a different approach based on historical returns. An early work by Diermeier, Ibbotson, and Siegel (1984) attempted to bolster the use of the DDM for long-range forecasting, but it was not widely used; the recent, and quite remarkable, revival of the DDM as an estimator of the equity premium dates back only to the late 1990s.

The second theme arose from Ibbotson and Sinquefield's 1976 article, which decomposed historical returns on an equity index into a part attributable to the riskless rate and a part attributable to the equity premium. The arithmetic mean of the equity premium part is assumed to be stationary-that is, the same in the future as in the past. Thus, if equities had beaten riskless Treasury bills by an arithmetic mean margin of 7 percent a year over the historical measurement period, which was usually 1926 through the then-current time, then equities were forecast to beat bills by the same amount in the future. This approach dominated practitioners' estimates of the equity premium starting in the late 1970s, but its influence has faded recently, under attack from both the DDM and the "puzzle" literature that began with Mehra and Prescott (1985).

Mehra and Prescott's 1985 article, "The Equity Premium: A Puzzle," began a third theme. The puzzle they described is that the historical equity risk premium during the period of 1889-1978 (or any other similarly long period, such as 1926 to the present) was too high, by at least an order of magnitude, to be explained by standard

1Myron J. Gordon and Eli Shapiro, “Capital Equipment Analysis: The Required Rate of Profit,” Management Science, vol. 3, no. 1 (October 1956):102-110. 
"general equilibrium" or "macroeconomic" asset-pricing models. Using these models, such a high premium can only be explained by a very high coefficient of risk aversion, one in the range of 30 to 40 . Risk aversion parameters observed in other aspects of financial behavior are around 1. So, Mehra and Prescott argued, either the model used to describe investors' behavior is flawed or equity investors have received a higher return than they expected.

We call the asset-pricing models referenced by Mehra and Prescott (1985) "macroeconomic" because they originated in that specialty, but more importantly to distinguish them from asset-pricing models commonly used in investment finance - such as the capital asset pricing model, the three-factor Fama-French model, and arbitrage pricing theory - that are silent on the absolute size of the risk premium (in fact, requiring it as an input) and that distinguish instead among the expected relative returns on specific securities or portfolios.

The rest of this introductory essay focuses on attempts to resolve the equity premium "puzzle" identified by Mehra and Prescott (1985). Their "puzzle" has stimulated a remarkable response in the academic literature. Most practitioners today, however, use estimates of the equity premium that emerge from the DDM-the earliest method. Moreover, practitioner debates tend to focus on which DDM estimate to use and the extent to which the estimate should be influenced by historical returns, not the question of whether either the DDM or the historical approach can be reconciled with that of Mehra and Prescott. Reflecting practitioners' concerns, this annotated bibliography covers all three major themes in the literature.

\section{Reconciling the "Puzzle"}

Research on the question of why the realized equity premium was so large can be grouped into two broad categories: (1) studies alleging bias in the historical data and (2) studies suggesting improvements in the macroeconomic model. A third category, studies that set forth methods for estimating for the equity risk premium independent of the macroeconomic model, is also addressed in this review.

Biases in Historical Data. Potential biases in the historical data vary from survivorship bias and variations in transaction and tax costs to the choice of short-term bills versus long-term bonds as the riskless asset.

Survivorship bias. Brown, Goetzmann, and Ross (1995) argued that the historical equity premium calculated using U.S. data is likely to overstate the true (expected) premium because the U.S. stock market turned out to be the most successful in world history. However, Dimson, Marsh, and Staunton (2006) examined stock and bond returns using data from 1900 to 2005 for 17 countries and concluded that the high historical equity premium obtained for the United States is comparable with that of other countries.

Transaction costs, regulations, and taxes. McGrattan and Prescott (2001) suggested that the higher historical equity premium is mainly because of a large run-up in the equity price caused by the sharp decline in the tax rate on dividends. In their 2003 article, they claimed that the equity premium is less than 1 percent after accounting for taxes, regulations, and costs.

Short-term bills vs. long-term bonds as the riskless asset. McGrattan and Prescott (2003) argued that shortterm bills provide considerable liquidity services and are a negligible part of individuals' long-term debt holdings. As a result, long-term bonds should be used as the riskless asset in equity premium calculations. Siegel (2005) argued that the riskless asset that is relevant to most investors (that is, to long-term investors) is "an annuity that provides a constant real return over a long period of time" (p. 63). And the return on long-term inflation-indexed government bonds is the closest widely available proxy for such an annuity.

Unanticipated repricing of equities. Bernstein (1997) suggested that because equities started the sample period (which begins in 1926) at a price-to-earnings ratio $(\mathrm{P} / \mathrm{E})$ of about 10 , and ended the period at a $\mathrm{P} / \mathrm{E}$ of about 20, the actual return on equities was higher than investors expected or required. Thus, the historical return overstates the future expected return. This finding was bolstered by Fama and French (2002), who used the DDM to show that investors expected an equity risk premium of about 3 percent, on average, from 1926 to the present.

Unanticipated poor historical bond returns. Historical bond returns may have been biased downward because of unexpected double-digit inflation in the 1970s and 1980s (Arnott and Bernstein 2002; Siegel 2005). However, subsequent disinflation and declines in bond yields have caused the bond yield to end the historical study period only a little above where it started, thus mostly negating the validity of this objection. 
Improvements in the Theoretical Model. The second broad category of research on the equity risk premium is a large body of literature exploring a variety of improvements in the original Mehra and Prescott (1985) model.

Rare events. Rietz (1988) suggested that the ERP puzzle can be solved by incorporating a very small probability of a very large drop in consumption. If such a probability exists, the predicted equity premium is large (to compensate investors for the small risk of a very bad outcome). In the same year, Mehra and Prescott countered that Rietz's model requires a 1 in 100 chance of a 25 percent decline in consumption to reconcile the equity premium with a risk aversion parameter of 10 , which is the approximate degree of risk aversion that would be required to predict an equity premium equal to that which was realized. ${ }^{2}$ However, they argued, the largest aggregate consumption decline in the last 100 years was only 8.8 percent. Campbell, Lo, and MacKinlay pointed out in 1997 that "the difficulty with Rietz's argument is that it requires not only an economic catastrophe, but one which affects stock market investors more seriously than investors in short-term debt instruments" (p. 311). ${ }^{3}$ Recently, Barro (2006) extended Rietz's model and argued that it does provide a plausible resolution of the equity premium "puzzle."

Recursive utility function. One critique of the power utility function used by Mehra and Prescott (1985) is the tight link between risk aversion and intertemporal substitution. Hall argued that this link is inappropriate because the intertemporal substitution concerns the willingness of an investor to move consumption between different time periods whereas the risk aversion parameter concerns the willingness of an investor to move consumption between states of the world. ${ }^{4}$ However, Weil (1989) showed that the ERP puzzle cannot be solved by simply separating risk aversion from intertemporal substitution. More recently, Bansal and Yaron (2004) argued that risks related to varying growth prospects and fluctuating economic uncertainty, combined with separation between the intertemporal substitution and risk aversion, can help to resolve the ERP puzzle.

Habit formation. Constantinides (1990) introduced habit persistence in an effort to explain the ERP puzzle. His model assumes that an investor's utility is affected by both current and past consumption and that a small fall in consumption can generate a large drop in consumption net of the subsistence level. This preference makes investors extremely averse to consumption risk even when risk aversion is small. Constantinides showed that the historical equity premium can be explained if past consumption generates a subsistence level of consumption that is about 80 percent of the normal consumption rate.

Abel defined a similar preference, called "catching up with the Joneses," where one's utility depends not on one's absolute level of consumption, but on how one is doing relative to others. 5

Borrowing constraints and life-cycle issues. Constantinides, Donaldson, and Mehra (2002) introduced lifecycle and borrowing constraints. They argued that as the correlation of equities with personal income changes over the life of the investor, so too does the attractiveness of equities to that investor. The young, who should borrow to smooth consumption and to invest in equities, cannot do so. Therefore, equities are priced almost exclusively by middle-aged investors, who find equities to be unattractive. Thus, equities are underpriced and bonds are overpriced, producing a higher equity risk premium than predicted by Mehra and Prescott (1985).

Limited market participation. Mankiw and Zeldes (1991) examined whether the consumption of stockholders differs from that of nonstockholders and whether this difference helps explain the historical equity risk premium. They showed that aggregate consumption of stockholders is more highly correlated with the stock market and is more volatile than the consumption of nonstockholders. A risk aversion parameter of 6 can explain the size of the equity premium based on consumption of stockholders alone. Although this value is still too large to be plausible, it is much less than the magnitude of 30 to 40 derived by Mehra and Prescott (1985) using the aggregate consumption data of both stockholders and nonstockholders.

\footnotetext{
${ }^{2}$ Rajnish Mehra and Edward C. Prescott, “The Equity Premium: A Solution?” Journal of Monetary Economics, vol. 22, no. 1 (July 1988):133-136. 3 John Y. Campbell, Andrew W. Lo, and A. Craig MacKinlay, The Econometrics of Financial Markets (Princeton, NJ: Princeton University Press, 1997).

4Robert E. Hall, “Intertemporal Substitution in Consumption,” Journal of Political Economy, vol. 96, no. 2 (December 1988):212-273.

5 Andrew B. Abel, "Asset Prices under Habit Formation and Catching Up with the Joneses," American Economic Review Papers and Proceedings, vol. 80, no. 2 (May 1990):38-42.
} 
Incomplete markets. Heaton and Lucas introduced uninsurable, idiosyncratic income risk into standard and dynamic general equilibrium models and showed that it can increase the risk premium. 6 Brav, Constantinides, and Geczy (2002) showed that the equity premium can be "explained with a stochastic discount factor calculated as the weighted average of the individual households' marginal rate of substitution with low and economically plausible values of the rate of risk aversion coefficient." This explanation relies on incomplete markets in that all risks would be insurable if markets were "complete."

Behavioral approach. Starting with prospect theory as proposed by Kahneman and Tversky, ${ }^{7}$ a large swath of behavioral finance literature argues that the combination of "myopic" loss aversion and narrow framing can help to resolve the ERP puzzle, including works by Benartzi and Thaler (1995), Barberis, Huang, and Santos (2001), and Barberis and Huang (2006).

\section{Summary}

The various (and quite different, almost unrelated) approaches to estimating the equity risk premium is best summarized by Ibbotson and Chen, who categorized the estimation methods into four groups: ${ }^{8}$

1. Historical method. The historical equity risk premium, or difference in realized returns between stocks and bonds (or stocks and cash), is projected forward into the future. See Ibbotson and Sinquefield (1976), which is updated annually by Ibbotson Associates (now Morningstar), and Dimson, Marsh, and Staunton (2002).

2. Supply-side models. This approach uses fundamental information, such as earnings, dividends, or overall economic productivity, to estimate the equity risk premium. See Diermeier, Ibbotson, and Siegel (1984); Siegel (1999); Shiller (2000); Fama and French (1999); Arnott and Ryan (2001); Campbell, Diamond, and Shoven (2001); Arnott and Bernstein (2002); and Grinold and Kroner (2002).

3. Demand-side models. This approach uses a general equilibrium or macroeconomic model to calculate the expected equity return by considering the payoff demanded by investors for bearing the risk of equity investments. Mehra and Prescott (1985) is the best known example of this approach, and the "puzzle debate" is an attempt to reconcile the results of this approach with the much higher ERP estimates given by the other approaches.

4. Surveys. An estimate of the equity risk premium is obtained by surveying financial professionals or academics (e.g., Welch 2000). Such results presumably incorporate information from the other three methods.

In closing, the equity risk premium has been the topic of intense and often contentious research over at least the last three decades. As Siegel (2005) said, although there are good reasons why the future equity risk premium should be lower than it has been historically, a projected equity premium of 2 percent to 3 percent (over longterm bonds) will still give ample reward for investors willing to bear the risk of equities.

\footnotetext{
6John Heaton and Deborah Lucas, "Evaluating the Effects of Incomplete Markets on Risk Sharing and Asset Pricing," Journal of Political Economy, vol. 104, no. 3 (June 1996):443-487.

7Daniel Kahneman and Amos Tversky, "Prospect Theory: An Analysis of Decisions under Risk," Econometrica, vol. 47, no. 2 (March 1979):263-292.

8Roger Ibbotson and Peng Chen, “The Supply of Stock Market Returns,” Ibbotson Associates, 2001.
} 


\section{Bibliography}

Aït-Sahalia, Yacine, Jonathan A. Parker, and Yogo Motohiro. 2004. "Luxury Goods and the Equity Premium." Journal of Finance, vol. 59, no. 6 (December):2959-3004.

This article proposes a partial solution to the ERP puzzle by distinguishing between the consumption of basic goods and that of luxury goods. The authors argue that the aggregate consumption does not measure the marginal risk of investing in the stock market. Using several novel datasets on luxury goods consumption, such as sales of imported luxury automobiles, this study shows that the covariance of luxury goods and excess returns implies a risk aversion parameter of 7 , significantly lower than that implied by aggregate consumption data.

Ang, Andrew, and Angela Maddaloni. 2005. "Do Demographic Changes Affect Risk Premiums? Evidence from International Data." Journal of Business, vol. 78, no. 1 (January):341-379.

This article examines empirically the relation between the equity risk premium and demographics using a long-term data sample (1900-2001) from the United States, Japan, the United Kingdom, Germany, and France as well as a shorter-term data sample (1970-2000) for 15 countries. By pooling international data, the authors show that a negative relation exists between the expected equity risk premium and the percentage of adults over 65 years old. The international results from this study support Abel's prediction that the equity risk premium is likely to decrease as the Baby Boom generation enters retirement. 9

Arnott, Robert D., and Clifford S. Asness. 2003. "Surprise! Higher Dividends = Higher Earnings Growth." Financial Analysts Journal, vol. 59, no. 1 (January/February):70-87.

Contrary to the predictions of Ibbotson and Chen (2003) and others who apply Modigliani and Miller $(\mathrm{M} \& \mathrm{M})$ dividend invariance intertemporally, earnings growth has been fastest when dividend payout is highest, not lowest, because of diminishing marginal productivity of capital. Thus, investors should not look to today's low payout ratios as a sign of stronger-than-historical earnings growth in the future.

Arnott, Robert D., and Peter L. Bernstein. 2002. "What Risk Premium Is 'Normal'?” Financial Analysts Journal, vol. 58, no. 2 (March/April):64-85.

The expected equity return equals the dividend yield, plus dividend growth, plus the expected change in valuation, if any. As of year-end 1925, investors expected about 5.1 percent (about 1.4 percent more than the bond yield). The subsequent positive surprise was because of four historical accidents: (1) bonds had unanticipated losses; (2) valuations quadrupled, as measured by the price-to-dividend ratio (P/D); (3) the market survived; and (4) accelerated growth in real dividends and earnings occurred because of regulatory reform. These observations are used to construct a framework for estimating the equity risk premium at each point in time, including the present. The "normal" equity risk premium, or historical average of what investors were actually expecting, is 2.4 percent, and the current equity risk premium is around zero.

\footnotetext{
${ }^{9}$ Andrew B. Abel, "Will Bequests Attenuate the Predicted Meltdown in Stock Prices when Baby Boomers Retire?" Review of Economics and Statistics, vol. 83, no. 2 (November 2001):589-595; "The Effects of a Baby Boom on Stock Prices and Capital Accumulation in the Presence of Social Security," Econometrica, vol. 71, no. 2 (March 2003):551-578.
} 
Arnott, Robert, and Ronald Ryan. 2001. "The Death of the Risk Premium: Consequences of the 1990s." Journal of Portfolio Management, vol. 27, no. 3 (Spring):61-74.

Applying the dividend discount model to then-current (January 2000) valuations produces an equity risk premium of -0.9 percent, consisting of a real equity expected return of 3.2 percent minus a real Treasury Inflation-Protected Securities (TIPS) yield of 4.1 percent. A similar analysis of the equity risk premium at the end of 1925 shows that it was 2.7 percent. Pension funds, especially (because of their liability characteristics), should invest more in bonds given these estimates.

Avramov, Doron, and Tarun Chordia. 2006. "Predicting Stock Returns." Journal of Financial Economics, vol. 82, no. 2 (November):387-415.

"The authors construct optimal portfolios that allow for company-level equity expected returns, variances, and covariances to vary conditional on a set of macroeconomic variables. Predictabilitybased investments outperform static and dynamic investments in the market, the Fama-French plus momentum factors, and strategies that invest in stocks with similar size, book-to-market, and prior return characteristics. Returns on individual stocks are predictable out-of-sample because of alpha variation, not because of equity premium predictability.” (Luis Garcia-Feijoo, CFA Digest, May 2007)

[Reference added April 2008]

Bansal, Ravi, and Amir Yaron. 2004. "Risk for the Long Run: A Potential Resolution of Asset Pricing Puzzles." Journal of Finance, vol. 59, no. 4 (August):1481-1509.

This article presents a model that can explain the equity risk premium. Dividend and, thus, consumption growth are assumed to consist of two components: a small persistent expected growth rate component and a time-varying economic uncertainty component. The authors show that the historical equity risk premium can be quantitatively justified by the model using a risk aversion parameter of 7.5 to 10 .

Barberis, Nicholas, and Ming Huang. 2006. “The Loss Aversion/Narrow Framing Approach to the Equity Premium Puzzle." In Handbook of Investments: Equity Risk Premium. Edited by Rajnish Mehra. Amsterdam: North Holland.

The authors review the behavioral approach to understanding the ERP puzzle. The key elements of this approach are loss aversion and narrow framing, two well-known features of decision making under risk in experimental settings. By incorporating these features into traditional utility functions, Barberis and Huang show that a large equity premium and a low and stable risk-free rate can be generated simultaneously, even when consumption growth is smooth and only weakly correlated with the stock market.

Barberis, Nicholas, Ming Huang, and Tano Santos. 2001. "Prospect Theory and Asset Prices." Quarterly Journal of Economics, vol. 116, no. 1 (February):1-53.

This paper proposes a new approach for pricing assets by incorporating two psychological ideas into the traditional consumption-based model. Investors are assumed to be more sensitive to losses than to gains, and their risk aversion changes over time depending on their prior investment outcomes. The authors show that this framework can help explain the high historical equity risk premium.

Barro, Robert. 2006. "Rare Disasters and Asset Markets in the Twentieth Century." Quarterly Journal of Economics, vol. 121, no. 3 (August):823-866.

This paper extends the analysis of Rietz (1988) and argues that it does provide a plausible resolution of the ERP puzzle. The author suggests that the rare-disasters framework (i.e., the allowance for lowprobability disasters proposed by Rietz) can explain the ERP puzzle while "maintaining the tractable framework of a representative agent, time-additive and iso-elastic preferences, and complete markets" (p. 823). These technical terms refer to assumptions that are embedded in Mehra and Prescott (1985) and that are considered standard in general equilibrium or macroeconomic models. 
Benartzi, Shlomo, and Richard H. Thaler. 1995. "Myopic Loss Aversion and the Equity Premium Puzzle." Quarterly Journal of Economics, vol. 110, no. 1 (February):73-92.

This article proposes an explanation for the equity premium based on two concepts from the psychology of decision making. The first concept is called "loss aversion," meaning that investors are more sensitive to losses than to gains. The second concept is called "mental accounting," which points out that investors mentally separate their portfolios into subportfolios for which they have quite different utility functions or risk aversion parameters. For example, investors may have one set of portfolios that they never evaluate and another set that they evaluate every day. Benartzi and Thaler show that the size of the historical equity premium can be explained if investors evaluate their portfolio at least annually.

Bernstein, Peter L. 1997. "What Rate of Return Can You Reasonably Expect... or What Can the Long Run Tell Us about the Short Run?” Financial Analysts Journal, vol. 53, no. 2 (March/April):20-28.

By studying historical intervals when stock valuation $(\mathrm{P} / \mathrm{D}$ or $\mathrm{P} / \mathrm{E})$ was the same at the end of the interval as at the beginning, one can avoid incorporating unexpected valuation changes into long-term rate of return studies. The analysis gives an equity risk premium of 3 percent, although the more interesting finding is that equity returns are mean-reverting whereas bond returns have no mean to which to regress. Thus, in the very long run and in real terms, stocks are safer than bonds.

Blanchard, Olivier J., Robert Shiller, and Jeremy J. Siegel. 1993. "Movements in the Equity Premium." Brookings Papers on Economic Activity, no. 2:75-138.

The authors show that the expected equity premium has gone steadily down since the 1950s from an unusually high level in the late 1930s and 1940s. Blanchard et al. show the positive relation between inflation and the equity premium, and they conclude that the equity premium is expected to stay at its current level of 2-3 percent if inflation remains low. Implications of this forecast for the macroeconomy are explored.

Bollerslev, Tim, George Tauchen, and Hao Zhou. 2009. "Expected Stock Returns and Variance Risk Premia.” Review of Financial Studies, vol. 22, no. 11 (November):4463-4492.

"The authors develop a stylized model to show that the difference between implied and realized variation, which they call the 'variance risk premium,' can explain a meaningful fraction of the stock returns during 1990-2007. Their findings indicate that higher premiums are associated with higher future returns, and vice versa." (Joanne Li, CFA Digest, May 2010)

[Reference added March 2010]

Brav, Alon, George M. Constantinides, and Christopher C. Geczy. 2002. "Asset Pricing with Heterogeneous Consumers and Limited Participation: Empirical Evidence." Journal of Political Economy, vol. 110, no. 4 (August):793-824.

This paper shows that the equity risk premium can be explained with a stochastic discount factor (SDF) calculated as the weighted average of the individual households' marginal rate of substitution. Important components of the SDF are cross-section variance and skewness of the households' consumption growth rates.

Brown, Stephen J., William N. Goetzmann, and Stephen A. Ross. 1995. “Survival.” Journal of Finance, vol. 50, no. 3 (July):853-873.

This paper suggests that survival could induce a substantial spurious equity premium and at least partially explain the equity premium puzzle documented by Mehra and Prescott (1985). (That is, to explain it away, because the returns used to frame the "puzzle" were neither expected nor were they achieved by many investors.) 
Campbell, John Y., Peter A. Diamond, and John B. Shoven. 2001. "Estimating the Real Rate of Return on Stocks over the Long Term.” Social Security Advisory Board. (www.ssab.gov/Publications/Financing/ estimated\%20rate\%20of\%20return.pdf)

This collection of papers presented to the Social Security Advisory Board explores expected equity rates of return for the purpose of assessing proposals to invest Social Security assets in the stock market.

Under certain stringent conditions, the earnings-to-price ratio $(\mathrm{E} / \mathrm{P})$ is an unbiased estimator of the expected equity return. Noting that earnings are highly cyclical, Campbell, in "Forecasting U.S. Equity Returns in the 21st Century," produces a more stable numerator for E/P by taking the 10-year trailing average of real earnings, E* (after Graham and Dodd;10 see also Campbell and Shiller 1998, Shiller 2000, and Asness ${ }^{11}$ ). From this perspective, current data suggest that the structural equity risk premium is now close to zero or that prices will fall, causing the equity risk premium to rise to a positive number. A little of each is the most likely outcome. Departing from the steady-state assumptions used to equate $\mathrm{E} / \mathrm{P}$ with the expected equity return and using a macroeconomic growth forecast and sensible assumptions about the division, by investors, of corporate risk between equities and bonds, a real interest rate of 3-3.5 percent is forecast, along with an equity risk premium of 1.5-2.5 percent geometric (3-4 percent arithmetic).

In "What Stock Market Returns to Expect for the Future?" Diamond explores the implications of an assumed 7 percent real rate of return on equities. Stocks cannot earn a real total return of 7 percent or else they will have a market capitalization of 39.5 times U.S. GDP by the year 2075 (assuming a 2 percent dividend-plus-share-buyback yield). In contrast, the current capitalization/GDP ratio is 1.5 . Changing the GDP growth rate within realistic bounds does not change the answer much. To justify a real total return of 7 percent, stocks must fall by 53 percent in real terms over the next 10 years (assuming a 2 percent dividend yield). Increasing the dividend payout does reduce the projected capitalization/GDP ratio materially, but in no case does it reduce the ratio below 7.86 in 2075 .

In "What Are Reasonable Long-Run Rates of Return to Expect on Equities?" Shoven examines what is likely to happen to rates of return over the next 75 years. Dividends are irrelevant, because of tax policy; what counts is total cash flow to the investor. In a steady state, the expected return on equities (per share) equals the dividend yield, plus the share buyback yield, plus the growth rate of macroeconomic aggregates. This analysis produces an expected real total return on equities of 6.125 percent (say, 6-6.5 percent). Because of high (3 percent) real rates as projected-not the very high, current TIPS yield-the equity risk premium is only 3-3.5 percent, but these projections require one to reduce the 7 percent real equity return projection used by the Social Security Advisory Board only a little. At a $\mathrm{P} / \mathrm{E}$ of 15 , the real equity return projection would be a little better than 7 percent.

Campbell, John Y., and Robert J. Shiller. 1998. "Valuation Ratios and the Long-Run Stock Market Outlook.” Journal of Portfolio Management, vol. 28, no. 2 (Winter):11-26. (Updated in Cowles Foundation Discussion Paper \#1295, Yale University, March 2001.)

The dividend-to-price ratio $(\mathrm{D} / \mathrm{P})$ can forecast either changes in dividend, which is what efficient market theory suggests, or changes in price, or both. Empirically, it forecasts only changes in price. At the current $\mathrm{D} / \mathrm{P}$, the forecast is extraordinarily bearish: The stock market will lose about two-thirds of its real value. The forecast becomes less drastically bearish (although still quite bearish) when one uses (dividend + share buybacks), earnings, the 10-year moving average of earnings in constant dollars, or other variables in the denominator. Real stock returns close to zero over the next 10 years are forecast. A number of statistical weaknesses in the analysis are acknowledged: The historical observations are not independent, and the analysis depends on valuation ratios regressing to their historical means, whereas the actual means are not known and could conceivably lie outside the historical range.

The 2001 update reaches the same conclusion and an even more bearish forecast.

${ }^{10}$ Benjamin Graham and David Dodd, Security Analysis (New York: McGraw-Hill, 1934).

11 Clifford S. Asness, "Stocks versus Bonds: Explaining the Equity Risk Premium," Financial Analysts Journal, vol. 56, no. 2 (March/ April 2000):96-113. 
Carhart, Mark M., and Kurt Winkelmann. 2003. “The Equity Risk Premium.” In Modern Investment Management. Edited by William N. Goetzmann and Roger G. Ibbotson. Hoboken, NJ: John Wiley \& Sons:44-54.

Historical perspective and an equilibrium estimate of the equity risk premium are discussed. The authors estimate that the U.S. corporate bond yield above Treasury bonds is 2.25 percent, and the expected U.S. corporate bond risk premium is thus 1.5 percent after subtracting an expected default loss of 0.75 percent. This amount (1.5 percent) is considered to be the lower bound of the current equity risk premium. Because equity volatility is two or three times higher than that of corporate bonds, the authors "cautiously" suggest an equity risk premium of 3 percent or higher.

Chen, Long, Ralitsa Petkova, and Lu Zhang. 2008. "The Expected Value Premium.” Journal of Financial Economics, vol. 87, no. 2 (February):269-280.

"This study uses dividend growth rates to determine whether an expected value premium exists $e x$ ante. The authors find the premium remained stable near 6.1 percent during the 1945-2005 period, consisting of a 4.4 percent dividend growth component and a 1.7 percent price ratio component. Results suggest that the relatively low profitability of value strategies in the 1990s most likely reflects cyclical movements rather than a permanent downward shift in the expected value premium." (Michael Kobal, CFA Digest, August 2008)

[Reference added March 2010]

Claus, James, and Jacob Thomas. 2001. "Equity Premia as Low as Three Percent? Evidence from Analysts' Earnings Forecasts for Domestic and International Stock Markets.” Journal of Finance, vol. 56, no. 5 (October):1629-1666.

The Ibbotson or historical-extrapolation method gives ERP estimates that are much too high, relative to both purely utility-based estimates (Mehra and Prescott 1985) and estimates based on valuation (for example, Campbell and Shiller 1998). Estimates of the equity risk premium were calculated for each year since 1985 by subtracting the 10 -year risk-free rate from the discount rate that equates U.S. stock market valuations with forecasted future flows, and results suggest that the equity risk premium is probably no more than 3 percent. International evidence from Canada, France, Germany, Japan, and the United Kingdom also support this claim. Known upward biases in analysts' earnings forecasts are corrected in making the estimates. Possible reasons why the historical method might have overstated the expected equity risk premium in recent years are discussed.

Cochrane, John H. 1997. "Where Is the Market Going? Uncertain Facts and Novel Theories." Economic Perspectives, Federal Reserve Bank of Chicago, vol. 21, no. 6 (November/December):3-37.

This paper summarizes the statistical evidence on average stock return and surveys economic theories that try to explain it. Standard models can only justify a low equity risk premium, whereas new models that can explain the 8 percent historical equity premium drastically modify the description of stock market risk. The author concludes that low forecast stock returns do not imply that the investor should change his portfolio unless he is different from the average investor in risk exposure, attitude, or information.

Constantinides, George M. 1990. "Habit Formation: A Resolution of the Equity Premium Puzzle." Journal of Political Economy, vol. 98, no. 3 (June):519-543.

Constantinides introduces habit persistence in an effort to explain the ERP puzzle. This model assumes that an investor's utility is affected by both current and past consumption and that a small drop in consumption can generate a large drop in consumption net of the subsistence level. The author shows that the historical equity premium can be explained if past consumption generates a subsistence level of consumption that is about 80 percent of the normal consumption rate. 
2002. "Rational Asset Prices." Journal of Finance, vol. 57, no. 4 (August):1567-1591.

This article examines the extent to which historical asset returns can be explained by relaxing the assumptions of the traditional asset pricing model. Constantinides reviews statistical evidence on historical equity returns and premiums and discusses the limitations of existing theories. The author suggests that it is promising to try to explain the equity risk premium by integrating the notions of incomplete market, life-cycle issues, borrowing constraints, and limited stock participation (i.e., stockholdings are concentrated in the hands of the wealthiest few), along with investors' deviation from rationality.

Constantinides, George M., John B. Donaldson, and Rajnish Mehra. 2002. "Junior Can't Borrow: A New Perspective on the Equity Premium Puzzle." Quarterly Journal of Economics, vol. 117, no. 1 (February):269-296.

As the correlation of equities with personal income changes over the life of the investor, so does the attractiveness of equities to that investor. The young, who should borrow to smooth consumption and to invest in equities, can't do so. Therefore, equities are priced almost exclusively by middle-aged investors, who find equities to be unattractive. (Middle-aged investors have a shorter time horizon and also prefer bonds because they smooth consumption in retirement, as wages do when one is working.) The result is a decreased demand for equities and an increased demand for bonds relative to what it would be in a perfectly competitive market. Thus, equities are (on average, over time) underpriced and bonds are overpriced, producing a higher equity risk premium than predicted by Mehra and Prescott (1985).

\section{Cornell, Bradford. 1999. The Equity Risk Premium. New York: Wiley.}

The literature on the equity risk premium is extensively reviewed and somewhat popularized in this book. The conclusion is that the equity risk premium will be lower in the future than it was in the past. A premium of 3.5-5.5 percent over Treasury bonds and 5-7 percent over Treasury bills is projected.

—. 2010. "Economic Growth and Equity Investing." Financial Analysts Journal, vol. 66, no. 1 (January/ February):54-64.

"The performance of equity investments is inextricably linked to economic growth. Nonetheless, few studies on investing have explicitly taken research on economic growth into account. This study bridges that gap by examining the implications for equity investing of both theoretical models and empirical results from growth theory. The study concludes that over the long run, investors should anticipate real returns on common stock to average no more than about 4 percent." (p. 54)

[Reference added March 2010]

Devaney, Michael. 2008. “Will Future Equity Risk Premium Decline?” Journal of Financial Planning, vol. 21, no. 4 (April):46-53.

"The equity risk premium (ERP) is the return an investor earns by investing in common stocks compared with the return earned on safe government bonds. The expected level of ERP can serve as a guide to asset allocation: An increasing ERP suggests a higher allocation to riskier equities, whereas a decreasing ERP suggests a larger allocation to low-risk debt. Although the expected level of ERP is of interest to investors, the fact is that disagreements occur among financial prognosticators regarding the future level of ERP." (Frank T. Magiera, CFA Digest, November 2008)

[Reference added March 2010] 
Dichev, Ilia D. 2007. "What Are Stock Investors' Actual Historical Returns? Evidence from Dollar-Weighted Returns." American Economic Review, vol. 97, no. 1 (March):386-401.

"For the NYSE and Amex, the author finds that dollar-weighted returns are 1.9 percent per year lower on average than value-weighted (or buy-and-hold) returns. For the NASDAQ, dollar-weighted returns are 5.3 percent lower. Similar results hold internationally. Because actual investor returns are lower than published returns, empirical measurements of the equity risk premium and companies' cost of equity are potentially overstated." (Bruce D. Phelps, CFA Digest, November 2007)

[Reference added April 2008]

Diermeier, Jeffrey J., Roger G. Ibbotson, and Laurence B. Siegel. 1984. “The Supply of Capital Market Returns.” Financial Analysts Journal, vol. 40, no. 2 (March/April):74-80.

Stock total returns must equal dividend yields plus the growth rate of dividends, which cannot, in the long run, exceed the growth rate of the economy. If infinite-run expected dividend growth exceeded infinite-run expected economic growth, then dividends would crowd out all other economic claims. Net new issues, representing new capital (transferred from the labor market) that is needed so the corporate sector can grow, may cause the dividend growth rate to be slower than the GDP growth rate. Thus, the equity risk premium equals the dividend yield (minus new issues net of share buybacks), plus the GDP growth rate, minus the riskless rate.

As far as we know, this is the first direct application of the dividend discount model of John Burr Williams (writing in the 1930s) and Myron Gordon and Eli Shapiro (in the 1950s) to the question of the equity risk premium for the whole equity market as opposed to an individual company. The "supply side" thread thus begins with this work.

Dimson, Elroy, Paul Marsh, and Mike Staunton. 2002. Triumph of the Optimists: 101 Years of Global Investment Returns. Princeton, NJ: Princeton University Press.

This book provides a comprehensive examination of returns on stocks, bonds, bills, inflation, and currencies for 16 countries over the period from 1900 to 2000. This evidence suggests that the high historical equity premium obtained for the United States is comparable with that of other countries. The point estimate of the historical equity premium for the United States and the United Kingdom is about 1.5 percent lower than reported in previous studies, and the authors attribute the difference to index construction bias (for the United Kingdom) and a longer time frame (for the United States). The prospective risk premium that investors can expect going forward is also discussed. The estimated geometric mean premium for the United States is 4.1 percent, 2.4 percent for the United Kingdom, and 3.0 percent for the 16-country world index. Implications for individual investors, investment institutions, and companies are carefully explored.

2003. "Global Evidence on the Equity Risk Premium." Journal of Applied Corporate Finance, vol. 15, no. 4 (Summer):27-38.

This article examines the historical equity risk premium for 16 countries using data from 1900 to 2002. The geometric mean annualized equity risk premium for the United States was 5.3 percent, and the average risk premium across the 16 countries was 4.5 percent. The forward-looking risk premium for the world's major markets is likely to be around 3 percent on a geometric mean basis and about 5 percent on an arithmetic mean basis.

2006. “The Worldwide Equity Premium: A Smaller Puzzle.” Working paper.

This paper is an updated version of Dimson, Marsh, and Staunton (2003). Using 1900-2005 data for 17 countries, the authors show that the annualized equity premium for the rest of the world was 4.2 percent, not too much below the U.S. equity premium of 5.5 percent over the same period. 
The historical equity premium is decomposed into dividend growth, multiple expansion, the dividend yield, and changes in the real exchange rate. Assuming zero change in the real exchange rate and no multiple expansion, and a dividend yield $0.5-1$ percent lower than the historical mean ( 4.49 percent), the authors forecast a geometric equity premium on the world index around 3-3.5 percent and 4.5-5 percent on an arithmetic mean basis.

Elton, Edwin J. 1999. "Presidential Address: Expected Return, Realized Return and Asset Pricing Tests." Journal of Finance, vol. 54, no. 4 (August):1199-1220.

At one time, researchers felt they had to (weakly) defend the assumption that expected returns were equal to realized returns. Now, they just make the assumption without defending it. This practice embeds the assumption that information surprises cancel to zero; evidence, however, shows they do not. The implications of this critique are applied to asset-pricing tests, not to the equity risk premium.

Fama, Eugene F., and Kenneth R. French. 1999. "The Corporate Cost of Capital and the Return on Corporate Investment.” Journal of Finance, vol. 54, no. 6 (December):1939-1967.

The authors use Compustat data to estimate the internal rate of return (IRR) of the capitalizationweighted corporate sector from 1950 to 1996 . This IRR, 10.72 percent, is assumed to have been the nominal weighted average cost of capital (WACC). By observing the capital structure and assuming a corporate debt yield 150 bps above Treasuries, and making the usual tax adjustment to the cost of debt, a nominal expected equity total return of 12.8 percent is derived, which produces an equity risk premium of 6.5 percent. The cash flow from the "sale" of securities in 1996 is a large proportion of the total cash flow studied, so the sensitivity of the result to the 1996 valuation is analyzed. Because the period studied is long, the result is not particularly sensitive to the exit price.

2002. "The Equity Premium.” Journal of Finance, vol. 57, no. 2 (April):637-659.

This paper compares alternative estimates of the unconditional expected stock return between 1872 and 2000, and provides explanation to the low expected return estimates derived from fundamentals such as dividends and earnings for the 1951-2000 period. The authors conclude that the decline in discount rates largely causes the unexplained capital gain of the last half-century.

Faugère, Christophe, and Julian Van Erlach. 2006. "The Equity Premium: Consistent with GDP Growth and Portfolio." Financial Review, vol. 41, no. 4 (November):547-564.

"Two macroeconomic equity premium models are derived and tested for consistency with historical data. The first model illustrates that the long-term equity premium is directly related to per capita growth in GDP. The second model, based on a portfolio insurance strategy of buying put options, illustrates that debtholders are paying stockholders an insurance premium, which is essentially the equity premium." (Stephen Phillip Huffman, CFA Digest, May 2007)

[Reference added April 2008]

Fisher, Lawrence, and James H. Lorie. 1964. "Rates of Return on Investments in Common Stocks." Journal of Business, vol. 37, no. 1 (January):1-21.

This paper presents the first comprehensive data on rates of return on investments in common stocks listed on New York Stock Exchange over the period from 1926 to 1960. The authors show that the annually compounded stock return was 9 percent with reinvestment of dividend for tax-exempt institutions during this period.

Geweke, John. 2001. "A Note on Some Limitations of CRRA Utility." Economic Letters, vol. 71, no. 3 (June): 341-345.

This paper points out that the equity premium calculated from the standard growth model in Mehra and Prescott (1985) is quite sensitive to small changes in distribution assumptions. As such, it is questionable to use this kind of growth model to interpret observed economic behavior. 
Goyal, Amit, and Ivo Welch. 2006. "A Comprehensive Look at the Empirical Performance of Equity Premium Prediction." Working paper.

This paper examines a wide range of variables that have been proposed by economists to predict the equity premium. The authors find that the prediction models have failed both in sample and out of sample using data from 1975 to 2004 and that out-of-sample predictions of the models are unexpectedly poor. They conclude that "the models would not have helped an investor with access only to the information available at the time to time the market" (p. 1).

Grinold, Richard, and Kenneth Kroner. 2002. “The Equity Risk Premium.” Investment Insights, Barclays Global Investors, vol. 5, no. 3 (July):1-24.

The authors examine the four components of the expected equity risk premium separately (income return, expected real earnings growth, expected inflation, and expected repricing) and suggest a current risk premium of about 2.5 percent. The authors argue that neither the "rational exuberance" view (5.5 percent equity risk premium) and "risk premium is dead" (zero or negative premium) view can be justified without making extreme and/or irrational assumptions.

The authors also forcefully attack the "puzzle" literature by arguing that literature on the equity risk premium puzzle is too academic and is dependent on unrealistic asset-pricing models.

Ibbotson, Roger G., and Peng Chen. 2003. "Long-Run Stock Returns: Participating in the Real Economy." Financial Analysts Journal, vol. 59, no. 1 (January/February):88-98.

If one simply uses the dividend discount model to forecast stock returns, the forecast violates M\&M dividend invariance because the current dividend yield is much lower than the average dividend yield over the period from which historical earnings growth rates were taken. Applying M\&M intertemporally, lower dividend payouts should result in higher earnings growth rates. The solution is to add, to the straight dividend discount model estimate, an additional-growth term of 2.28 percent as well as using a current-dividend number of 2.05 percent, which is what the dividend yield would have been in 2000 if the dividend payout ratio had equaled the historical average of 59.2 percent. The equity risk premium thus estimated is about 4 percent (geometric) or 6 percent (arithmetic), about 1.25 percent lower than the straight historical estimate.

Ibbotson, Roger G., and Rex A. Sinquefield, 1976. "Stocks, Bonds, Bills and Inflation: Year-by-Year Historical Returns (1926-74).” Journal of Business, vol. 49, no. 1 (January):11-47. (Updated in Stocks, Bonds, Bills and Inflation: 2006 Yearbook; Chicago: Morningstar, 2006.)

Total equity returns consist of a stationary part (the equity risk premium) and a nonstationary part (the interest rate component, which consists of a real interest rate plus compensation for expected inflation). The estimator of the future arithmetic mean equity risk premium is the past arithmetic mean premium, which is currently about 7 percent. To this is added the current interest rate, 4.8 percent (on 20-year Treasury bonds). The sum of these, about 12 percent, is the arithmetic mean expected total return on equities. This method is justified by the assertion that in the long run, investors should and do conform their expectations to what is actually realizable. As a result, the historical equity risk premium reflects equilibrium at all times and forms the proper estimator of the future equity risk premium. (Note that the 2006 update discusses other methods rather than supporting a doctrinaire "future equals past" interpretation of historical data.) 
Jagannathan, Ravi, Ellen R. McGrattan, and Anna Scherbina. 2000. "The Declining U.S. Equity Premium.” Quarterly Review, Federal Reserve Bank of Minneapolis, vol. 24, no. 4 (Fall):3-19.

The IRR equating expected future dividends from a stock portfolio with the current price is the expected total return on equities; subtracting the bond yield, one arrives at the equity risk premium. This number is estimated at historical points in time and is shown to have declined over the sample period (1926-1999). The expected total return on equities is about the same in the 1990s as it was in the 1960s, but the equity risk premium is smaller because bond yields have increased. The equity risk premium in 1999 is -0.27 percent for the S\&P 500, -0.05 percent for the "CRSP portfolio," and 2.71 percent for the "Board of Governors stock portfolio" (a broad-cap portfolio with many small stocks that pay high dividend yields). The analysis is shown to be reasonably robust when tested for sensitivity to the dividend yield being too low because of share repurchases and the bond yield being too high. If dividend growth is assumed equal to GNP growth, instead of being 1.53 percentage points lower as it was historically, then the equity risk premium based on the S\&P 500 rises to 1.26 percent.

Jorion, Philippe, and William N. Goetzmann. 1999. "Global Stock Markets in the Twentieth Century.” Journal of Finance, vol. 54, no. 3 (June):953-980.

The U.S. equity market experience in the 20th century is an unrepresentative sample of what can and does happen. The high equity risk premium observed globally is mostly a result of high equity returns in the United States (with a 4.3 percent real capital appreciation return), which had a large initial weight in the GDP-weighted world index. All other surviving countries had lower returns (with a median real capital appreciation return of 0.8 percent), and there were many nonsurviving countries. Although the large capitalization of the United States was in a sense the market's forecast of continued success, investors did not know in advance that they would be in the highest-returning country or even in a surviving one. Nonsurvival or survival with poor returns should be factored in when reconstructing the history of investor expectations (and should conceivably be factored into current expectations too). This finding contrasts with that of Dimson, Marsh, and Staunton (2002, 2003, 2006).

Kocherlakota, Narayana R. 1996. "The Equity Premium: It Is Still a Puzzle.” Journal of Economic Literature, vol. 34, no. 1 (March):42-71.

After reviewing the literature on modifications of investor risk preference and on market friction, the author suggests that the ERP puzzle is still unsolved. Kocherlakota concludes that the equity risk premium puzzle should be solved by discovering the fundamental features of goods and asset markets rather than patching existing models.

Kritzman, Mark P. 2001. “The Equity Risk Premium Puzzle: Is It Misspecification of Risk?” Economics and Portfolio Strategy (15 March), Peter L. Bernstein, Inc.

Investors do not know when they are going to need their money back (for consumption), so the terminal-wealth criterion used by Mehra and Prescott (1985) to frame the ERP puzzle greatly understates the risk of equities (but not of bonds). In addition, some investors face risk from "breaching a threshold" that is not captured by classical utility theory. Thus, a much higher equity risk premium is justified by utility theory than is proposed by Mehra and Prescott. 
Longstaff, Francis A., and Monika Piazzesi. 2004. "Corporate Earnings and the Equity Premium." Journal of Financial Economics, vol. 74, no. 3 (December):401-421.

Most studies assume that aggregate dividends equal aggregate consumption. This article argues that separating corporate cash flow from aggregate consumption is critical because "corporate cash flows have historically been far more volatile and sensitive to economic shocks than has aggregate consumption" (p. 402). The authors show that the equity premium consists of three components, identified by allowing aggregate dividends and consumption to follow distinct dynamic processes. The first component is called the consumer-risk premium, which is the Mehra and Prescott (1985) equity risk premium proportional to the variance of consumption growth. The second component is the eventrisk premium, which compensates for downward jumps. And the third component is the corporaterisk premium, which is proportional to the covariance between the consumption growth rate and the "corporate fraction" (defined as the ratio of aggregate dividends to consumption). Using a risk aversion parameter of 5 , the three components are 0.36 percent, 0.51 percent, and 1.39 percent, summing to a total equity premium of 2.26 percent. The authors admit that their model does not solve the ERP puzzle completely and suggest that the ultimate resolution may lie in the integration of their model with other elements, such as habit formation or investor heterogeneity in incomplete markets.

Lundblad, Christian. 2007. “The Risk Return Tradeoff in the Long Run: 1836-2003.” Journal of Financial Economics, vol. 85, no. 1 (July):123-150.

"Although the risk-return trade-off is fundamental to finance, the empirical literature has offered mixed results. The author extends the sample considerably and analyzes nearly two centuries of both U.S. and U.K. market returns and finds a positive and statistically significant risk-return trade-off in line with the postulated theory." (Yazann S. Romahi, CFA Digest, February 2008)

[Reference added April 2008]

Mankiw, N. Gregory. 1986. “The Equity Premium and the Concentration of Aggregate Shocks.” Journal of Financial Economics, vol. 17, no. 1 (September):211-219.

This article shows that one cannot judge the appropriateness of the equity premium from aggregate data alone, as Mehra and Prescott (1985) did. In an economy where aggregate shocks are not dispersed equally throughout the population, the equity premium depends on the concentrations of these aggregate shocks in particular investors and can be made arbitrarily large by making the shock more and more concentrated.

Mankiw, N. Gregory, and Stephen P. Zeldes. 1991. "The Consumption of Stockholders and Non-Stockholders." Journal of Financial Economics, vol. 29, no. 1 (March):97-112.

This article examines whether the consumption of stockholders differs from that of nonstockholders and whether this difference helps to explain the historical equity risk premium. It shows that aggregate consumption of stockholders is more highly correlated with the stock market and is more volatile than the consumption of nonstockholders. A risk aversion parameter of 6 (relative to the magnitude of 30-40 in Mehra and Prescott 1985) can explain the size of the equity premium based on consumption of stockholders alone.

McGrattan, Ellen R., and Edward C. Prescott. 2000. “Is the Stock Market Overvalued?” Quarterly Review, Federal Reserve Bank of Minneapolis (Fall):20-40.

Standard macroeconomic growth theory (Cobb-Douglas, etc.) is used to value the corporate sector in the United States. The current capitalization-to-GDP ratio of 1.8 is justified, so the market is not overvalued. "[T] heory ... predicts that the real returns on debt and equity should both be near 4 percent" (p. 26). Thus, the predicted equity risk premium is small. 
2001. “Taxes, Regulations, and Asset Prices.” NBER Working Paper \#8623.

This paper shows that the large run-up in equity value relative to GDP between 1962 and 2000 is mainly caused by (1) large reductions in individual tax rates, (2) increased opportunities to hold equity in a nontaxed pension plan, and (3) increases in intangible and foreign capital. The authors argue that the high equity risk premium documented by Mehra and Prescott (1985) is not puzzling after these three factors are accounted for. However, in the future, one should expect no further gains from tax policy; the currently expected real return on equities is about 4 percent, down from 8 percent in the early postwar period.

—. 2003. “Average Debt and Equity Returns: Puzzling?” American Economic Revierw, vol. 93, no. 2 (May):392-397.

This article shows that the realized equity premium in the last century was less than 1 percent after accounting for taxes, regulations, and diversification costs. The authors also argue that Treasury bills "provide considerable liquidity services and are a negligible part of individuals' long-term debt holdings” (p. 393). Long-term savings instruments replace short-term government debt in their equity premium calculation.

Mehra, Rajnish. 2003. “The Equity Premium: Why Is It a Puzzle?” Financial Analysts Journal, vol. 59, no. 1 (January/February):54-69.

The ERP puzzle literature is easily misunderstood because of its difficulty. Here, the puzzle is stated in language that is accessible to most finance practitioners. First, empirical facts regarding the returns and risks of major asset classes are presented. Then, the theory responsible for the "puzzle" is summarized. Modern asset pricing theory assumes that economic agents pursue and, on average, get fair deals. When one follows this line of reasoning to its conclusion, using the tools of classic growth and real business cycle theory, an equity risk premium of at most 1 percent emerges. An extensive discussion reveals why this is the case and addresses various attempts made by other authors to resolve the puzzle.

Mehra, Rajnish, and Edward C. Prescott. 1985. "The Equity Premium: A Puzzle.” Journal of Monetary Economics, vol. 15, no. 2 (March):145-161.

In this seminal work, Mehra and Prescott first document the "equity premium puzzle" using a consumption-based asset-pricing model in which the quantity of risk is defined as the covariance of excess stock return with consumption growth and the price of risk is the coefficient of relative risk aversion. Because of the low risk resulting from the smooth historical growth of consumption, the 6 percent equity risk premium in the 1889-1978 period can only be explained by a very high coefficient of risk aversion in the magnitude of 30 to 40. Risk aversion parameters observed in other aspects of financial behavior are around 1 . Such a risk aversion parameter is consistent with at most a 1 percent equity risk premium, and possibly one as small as 0.25 percent.

Note that Mehra and Prescott assumed that consumption was equal to aggregate dividends. Because consumption is very smooth and dividends are not as smooth, this comparison may be troublesome.

Philips, Thomas K. 1999. "Why Do Valuation Ratios Forecast Long-Run Equity Returns?" Journal of Portfolio Management, vol. 25, no. 3 (Spring):39-44.

In this article, the Edwards-Bell-Ohlson equation,

$$
P_{0}=B_{0}+\sum_{i=1}^{\infty}\left\{\frac{E\left[\left(R O E_{i}-r\right) B_{i-1}\right]}{(1+r)}\right\} \text {, }
$$


where $P$ is price, $B$ is book value, $R O E$ is return on book equity, $r$ is the expected return on equity, and $i$ is the time increment, is first used to derive closed-form expressions for the expected return on equities, stated in terms of both dividends and earnings. Then, the GDP growth rate is introduced as an indicator of earnings growth. Share repurchases are considered to be a part of dividends. This setup leads to the following conclusions: (1) The expected return increases monotonically with book-toprice ratio $(\mathrm{B} / \mathrm{P}), \mathrm{E} / \mathrm{P}$, and $\mathrm{D} / \mathrm{P} ;(2)$ if a corporation's return on equity equals its cost of capital (expected return), then its price-to-book ratio (P/B) should be 1 and its expected return should equal $\mathrm{E} / \mathrm{P}$. The analysis suggests that nominal total expected equity returns shrank from almost 14 percent in 1982 to 6.5 percent in 1999 (a larger decline than can be explained by decreases in unanticipated inflation). This decrease in expected return was accompanied by very high concurrent actual returns that were misread by investors as evidence of an increase in the expected return. Going forward, investors will not get an increased return.

Rietz, Thomas A. 1988. “The Equity Risk Premium: A Solution.” Journal of Monetary Economics, vol. 22, no. 1 (July):117-131.

Rietz suggests that the ERP puzzle can be solved by incorporating a very small probability of a very large drop in consumption. In such a scenario, the risk-free rate is much lower than the equity return. In an article published in the same issue, Mehra and Prescott argued that Rietz's model requires a 1 in 100 chance of a 25 percent decline in consumption to reconcile the equity premium with a risk aversion parameter of 10 . However, the author says, the largest consumption decline in the last 100 years was only 8.8 percent. Campbell, Lo, and MacKinlay (see Note 3) point out that "the difficulty with Rietz's argument is that it requires not only an economic catastrophe, but one which affects stock market investors more seriously than investors in the short-term debt instruments” (p. 311).

But during the Great Depression, the stock market fell by 86 percent from peak to trough and dividends fell by about half; consumption by stockholders over that period thus probably fell by much more than 8.8 percent. Aggregate consumption at that time included many lower-income people, especially farmers, whose consumption was not directly affected by falling stock prices.

Shiller, Robert J. 2000. Irrational Exuberance. Princeton, NJ: Princeton University Press.

This influential book provides a wealth of historical detail on the equity risk premium. Using 10 years of trailing real earnings (see, originally, Graham and Dodd) to estimate normalized P/Es, Shiller concludes that the market is not only overpriced but well outside the range established by previous periods of high stock prices.

Siegel, Jeremy J. 1999. “The Shrinking Equity Premium.” Journal of Portfolio Management, vol. 26, no. 1 (Fall):10-19. In contrast to Siegel (2002), analysis of dividend and earnings multiples suggests a real return (not an equity risk premium) of only 3.1-3.7 percent for stocks, lower than the then-current real TIPS yield. Although then-current high prices suggest higher-than-historical earnings growth, investors are likely to realize lower returns than in the past. (Incidentally, past achieved returns are lower than index returns because of transaction costs and lack of diversification.) On the positive side, the Jorion and Goetzmann (1999) finding that world markets returned a real capital gain of only 0.8 percent from 1921 to the present, compared with 4.3 percent in the United States, is misstated because the analysis is of the median portfolio, not the average. The GDP-weighted average is only 0.28 percent short of the U.S. return and is higher than the U.S. return if converted to dollars (although Jorion and Goetzmann point out that the large initial size of the United States causes the annualized world index return to lie within 1 percent of the U.S. return by construction). 
2002. Stocks for the Long Run. 3rd ed. New York: McGraw-Hill.

Siegel argues for a U.S. equity risk premium of 2-3 percent, about half of the historic equity risk premium. He expects a future real return on equity of about 6 percent, justified by several positive factors. Siegel considers an equity risk premium as low as 1 percent but clearly sees that stocks must yield more than inflation-indexed bond yields ( 3.5 percent at the time of the book). He turns to earnings yield arguments to answer the question of how much more. A Tobin's $q$ greater than 1 in 2001 leads Siegel to see the earnings yield as understated. In addition, the overinvestment in many technology companies led to a drop in the cost of productivity-enhancing investments, which allows companies to buy back shares or raise dividends. In technology, an excess supply of capital, overbuilding, and a subsequent price collapse provide a technological base to benefit the economy and future shareholder returns. Also, the United States is still seen as an entrepreneurial nation to attract a growing flow of investment funds seeking a safe haven, leading to higher equity prices. Furthermore, short-run room for growth in corporate profits is another positive factor for future real return enhancement.

- 2005. "Perspectives on the Equity Risk Premium." Financial Analysts Journal, vol. 61, no. 6 (November/ December):61-73.

This article reviews and discusses the ERP literature as follows: (1) a summary of data used in equity premium calculation and their potential biases, (2) a discussion of academic attempts to find models to fit the data, (3) the practical applications of some proposed models, and (4) a discussion of the future equity risk premium.

Siegel, Jeremy J., and Richard H. Thaler. 1997. “Anomalies: The Equity Premium Puzzle.” Journal of Economic Perspectives, vol. 11, no. 1 (Winter):191-200.

Proposed resolutions of the ERP puzzle fall into two categories: (1) observations that the stock market is riskier, or the equity risk premium is smaller, than generally thought, and (2) different theoretical frameworks that would make the observed risk aversion rational. Neither approach has been "completely successful" in explaining why, if stocks are so rewarding, investors don't hold more of them.

Weil, Philippe. 1989. "The Equity Premium Puzzle and the Risk-Free Rate Puzzle.” Journal of Monetary Economics, vol. 24, no. 3 (November):401-421.

A critique of the power utility function used by Mehra and Prescott (1985) is the tight link between risk aversion and intertemporal substitution. This article shows that the ERP puzzle cannot be solved by simply separating risk aversion for intertemporal substitution.

Weitzman, Martin L. Forthcoming. "Prior-Sensitive Expectations and Asset-Return Puzzles." American Economic Revierw.

This article presents one unified Bayesian theory that explains the ERP puzzle, risk-free rate puzzle, and excess volatility puzzle. The author shows that Bayesian updating of unknown structural parameters introduces a permanent thick tail to posterior expectation that can account for, and even reverse, major asset-return puzzles.

Welch, Ivo. 2000. "Views of Financial Economists on the Equity Premium and Professional Controversies." Journal of Business, vol. 73, no. 4 (October):501-537.

This paper presents the results of a comprehensive survey of 226 financial economists. The main findings are: (1) the average arithmetic 30-year equity premium forecast is about 7 percent; (2) shortterm forecasts are lower than the long-term forecast, in the range of 6-7 percent; (3) economists perceive that their consensus is about $0.5-1$ percent higher than it actually is. 
2001. "The Equity Premium Consensus Forecast Revisited." Working paper, Yale University.

The equity premium forecast in this 2001 survey declined significantly compared with the 1998 survey.

The one-year forecast is 3-3.5 percent, and the 30-year forecast stands at 5-5.5 percent.

Welch, Ivo, and Amit Goyal. 2008. "A Comprehensive Look at the Empirical Performance of Equity Premium Prediction.” Review of Financial Studies, vol. 38, no. 1 (July):65-67.

"The authors review the evidence on the ability of linear models to predict the equity premium (i.e., the difference between the equity return and the risk-free rate). They identify the properties necessary for an equity premium prediction model to be useful for investment decision making: significant insample and good out-of-sample performance during the entire sample period, performance that does not rely on strong prediction performance during just a few years, and good performance during the past 30 years. Using a long time series of annual data that begins in 1871, the authors find that no equity prediction model has been successful and that investors are better off assuming that next period's equity premium will be the average premium. The authors also examine longer-horizon (five years) and shorter-horizon (one month) prediction performance. They are unable to find any model reliable enough to guide investment strategy." (Bruce D. Phelps, CFA Digest, February 2009)

[Reference added March 2010]

I would like to thank Laurence Siegel, research director of the Research Foundation of CFA Institute, for his assistance and for providing much of the foundation for this project with his earlier work on the equity risk premium. I am also grateful to the Research Foundation for financial support.

This publication qualifies for $1 \mathrm{CE}$ credit. 